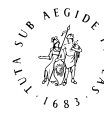

\title{
Advancing Wood Identification - Anatomical and Molecular Techniques
}

\author{
Yafang Yin, Alex C. Wiedenhoeft, and Lloyd Donaldson (editors)
}

The adoption of wood anatomy for identification has been well-established for more than 100 years to separate genera or species groups but today's demand for forensic wood identification requires discrimination of wood at the species level and determination of the origin of timber, especially for enforcement of legal logging. Recent advances in artificial intelligence, biotechnology, and chemical analysis, including computer vision, DNA typing, and chemotyping with spectroscopic and spectrometric methods for wood show the capacity to improve upon wood anatomy-based identifications. The application of the new techniques to identify species and track the geographic origin of internationally traded timber has attracted increasing interest as a potential part of global systems to support sustainable forestry, to promote legal timber harvest, and to combat illegal logging. This special edition includes major studies investigating the identification of charcoal and particle board, a review of DNA barcoding, and several investigations using computer-assisted, chemometric, and machine learning techniques. All these reports support the broader theme of tracing the origins of timber and wood products in international trade.

To review the progress and new applications of technology in this field, an IAWA-IUFRO international symposium "Challenges and opportunities for updating wood identification" was organized in May 2019 in Beijing, China. To leverage the success of the symposium and disseminate recent research advances in wood identification, the IAWA Journal is publishing this new special edition containing 14 original papers and one review article emphasizing recent developments in wood anatomy and multidisciplinary approaches, as an update to the weighty special edition [2011, 32(2)] "Wood science for promoting legal timber harvest" published in the Journal nine years before.

In addition to new forensic techniques, the establishment of a global network of wood collections/databases and scientists to share relevant data, information, and tools for wood identification is rapidly becoming of increasing importance (e.g. Global Timber Tracking Network). A new IUFRO Research Group-5.16.oo Wood Identification was established in September 2020. IAWA will take this opportunity to strengthen its collaboration with IUFRO and other relevant international/regional organizations (e.g. CITES, ITTO, and IAWS) to play a vital leading role in the research, development, and innovation of global wood identification.

We thank the authors and referees of this special edition for their great contributions. The support of the Chinese Academy of Forestry (CAF), China National Forestry and 
Grassland Administration (NFGA), IAWA, IUFRO, USDA Forest Products Laboratory, German Federal Ministry of Food and Agriculture (BMEL), Global Timber Tracking Network (GTTN), and all colleagues from the 2019 IAWA-IUFRO international symposium and this special issue of the IAWA Journal is gratefully acknowledged.

\section{REFERENCES}

Abe H, Kurata Y, Watanabe K, Ishikawa A, Noshiro S, Fujii T, Iwasa M, Kaneko H, Wada H. 2020. The separation of softwood and hardwood in historical wooden statues of the Nazenji-temple in Japan using NIR spectroscopy. IAWA 41(4): 740-75o. DOI: 10.1163/22941932-bja1oo38.

Andrade BG, Basso VM, Latorraca JVF. 202O. Machine vision for field-level wood identification. IAWA 41(4): 681-698. DOI: 10.1163/22941932-bja1ooo1.

Brandes AFDN, Novello BQ, Lemos DN, Nascimento LB, Albuquerque RP, Tamaio N, Barros CF. 2020. Wood anatomy of endangered Brazilian tree species. IAWA 41(4):510-576. DOI: 10.1163/22941932bja10o37.

Carmona RJ, Wiemann MC, Baas P, Barros C, Chavarria GD, McClure PJ, Espinoza EO. 2O2O. Forensic identification of CITES Appendix I Cupressaceae using anatomy and mass spectrometry. IAWA 41(4): 720-739. DOI: 10.1163/22941932-bja1ooo2.

Haag V, Zemke VT, Lewandrowski T, Zahnen J, Hirschberger P, Bick U, Koch G. 2020. The European charcoal trade. IAWA J. 41(4): 463-477. DOI: 10.1163/22941932-bja1oo17.

Jahanbanifard M, Beckers V, Koch G, Beeckman H, Gravendeel B, Verbeek F, Baas P, Priester C, Lens F. 2020. Description and evolution of wood anatomical characters in the ebony wood genus Diospyros and its close relatives (Ebenaceae): A first step towards combatting illegal logging. IAWA 41(4): 577-619. DOI: 10.1163/22941932-bja10o40.

Jiao L, Lu Y, He T, Guo J, Yin Y. 2020. DNA Barcoding for wood identification: Global review of the last decade and future perspective. IAWA 41(4): 620-643. DOI: 10.1163/22941932-bja1oo41.

Lens F, Liang C, Guo Y, Tang X, Jahanbanifard M, da Silva FSC, Ceccantini G, Verbeek FJ. 2020. Computer-assisted timber identification based on features extracted from microscopic wood sections. IAWA 41(4): 66o-68o. DOI: 10.1163/22941932-bja1oo29.

Lu Y, Jiao L, He T, Zhang Y, Jiang X, Yin Y. 2020. An optimized DNA extraction protocol for wood DNA barcoding of Pterocarpus erinaceus. IAWA 41(4): 644-659. DOI: 10.1163/22941932-bja1ooo6.

Perdigão CRV, Júnior MMB, Gonçalves TAP, Araujo CS, Mori FA, Barbosa ACMC, Souza FIB, Motta JP, Melo LEM. Forestry control in the Brazilian Amazon I: Wood and charcoal anatomy. IAWA 41(4): 490-507. DOI: 10.1163/22941932-bja10o16.

Ruffinatto F, Castro G, Cremonini C, Crivellaro A, Zanuttini R. 202O. A new atlas and macroscopic wood identification software package for Italian timber species. IAWA J. 41(4): 393-411. DOI: 10. $1163 / 22941932$-Oooo2102.

Sieburg-Rockel J, Koch G. 2020. Identification of wood species used in particleboard production. IAWA 41(4): 751-76o. DOI: 10.1163/22941932-bja1oo18.

Wheeler EA, Gasson PE, Baas P. 2020. Using the InsideWood web site: Potentials and pitfalls. IAWA J. 41(4): 412-462. DOI: $10.1163 / 2294193^{2}$-bja1oo32.

Wiedenhoeft A. 2020. XyloPhone: democratizing access to high-quality macroscopic imaging for wood and other substrates. IAWA 41(4): 699-719. DOI: 10.1163/22941932-bja1oo43.

Zemke V, Haag V, Koch G. 202O. Wood identification of charcoal with 3 D-reflected light microscopy. IAWA 41(4): 478-489. DOI: 10.1163/22941932-bja1oo33. 